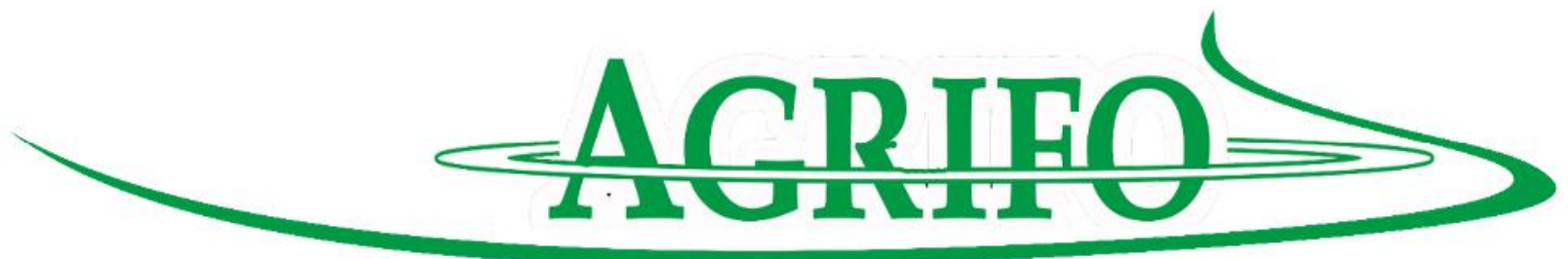

\title{
PERAN KOPERASI KOPI TERHADAP PRODUKSI DAN KESEJAHTERAAN PETANI KOPI DI KECAMATAN BANDAR KABUPATEN BENER MERIAH
}

\section{Edwin Stiyawan ${ }^{1}$, Fadli $^{2}$ dan Ellyta Effendy ${ }^{3}$}

${ }^{1}$ Program Studi Agribisnis Fakultas Pertanian

${ }^{2,3}$ Staff Pengajar Program Studi Agribisnis Universitas Malikussaleh

\begin{abstract}
ABSTRAK
Peran koperasi adalah suatu peran badan usaha yang bekerja sama dengan masyarakat dalam meningkatkan taraf kehidupan petani yang lebih baik. Tujuan penelitian menganalisis peran koperasi terhadap produksi kopi dan kesejahteraan petani. Metode analisis data menggunakan skala likert. Hasil penelitian ini menjelaskan bahwa peran koperasi kopi sebagai penyuluh, penyediaaan pupuk organik, premi, dan jumlah produksi sangat besar. Sedangkan peran koperasi sebagai penyediaan bibit kopi dan penampungan hasil berada pada kategori besar. Secara keseluruhan peran koperasi kopi terhadap produksi dan kesejahteraan petani di Kecamatan Bandar mempunyai peran sangat besar.
\end{abstract}

Kata kunci : Peran Koperasi, Produksi, Kesejahteraan, Kopi

\section{PENDAHULUAN}

Kopi merupakan salah satu komoditi yang sangat diunggulkan dan diharapkan dapat berperan sebagai sumber salah satu penghasil devisa Negara, sumber pendapatan bagi petani, penciptaan lapangan kerja, pendorong agribisnis dan agroindustri serta pengembangan wilayah (Hasan, 2011).

\section{Kabupaten Bener Meriah} merupakan salah satu kabupaten yang memiliki luas areal perkebunan kopi mencapai 43.765,75 Ha (Dinas Perkebunan dan Kehutanan Kabupaten Bener Meriah, 2013).
Sektor perkebunan kopi merupakan sektor andalan Kabupaten Bener Meriah. Hal ini dapat ditinjau dari segi potensi, kesediaan lahan yang cukup mendukung, serta mayoritas penduduknya bermata pencaharian sebagai petani kopi mulai dari Kecamatan Pintu Rime Gayo, Gajah Putih, Timang Gajah, Wih Pesam, Bukit, Bandar, dan Potensi besar ini diharapkan dapat meningkatkan produksi kopi, tetapi produksi kopi yang dihasilkan terus mengalami penurunan. Kodisi tersebut dapat dilihat pada Tabel 1 berikut. 
Tabel 1. Hasil Produksi dan Luas Lahan Kopi Di Kabupaten Bener Meriah dari Tahun 2008 - 2012.

\begin{tabular}{rlrr}
\hline No & Tahun & Produksi (Ton) & \multicolumn{1}{c}{ Luas lahan (Ha) } \\
\hline 1 & 2008 & $25.305,03$ & $39.490,01$ \\
2 & 2009 & $21.404,05$ & $45.316,04$ \\
3 & 2010 & $18.660,30$ & $45.316,04$ \\
4 & 2011 & $15.937,82$ & $43.765,74$ \\
5 & 2012 & $15.508,24$ & $43.765,75$
\end{tabular}

Sumber Data: Dinas Perkebunan dan Kehutanan Kabupaten Bener Meriah, 2013

Kecamatan Bandar memiliki produktivitas paling rendah yaitu 0,319 Ton/Ha, Nilai produktivitas dikecamatan Bandar masih jauh dari produktivitas kopi jenis arabika maupun jenis robusta tingkat nasional yaitu mencapai 0,700-0,800 Ton/Ha. Tingginya produksi dikecamatan Bandar bukan menunjukkan produksi optimal yang bisa dihasilkan, akan tetapi karena luas lahan usahatani kopi dikecamatan tersebut yang lebih besar, Oleh karena itu perlu upaya untuk meningkatkan produksi selain dari peningkatan luas areal tanam (Abdurachman, Dariah, \& Mulyani, 2008).

Pemerintah Kabupaten Bener
Meriah terus berupaya mencari
terobosan - terobosan dalam
meningkatkan produksi kopi dengan

Pemerintah Kabupaten Bener Meriah terus berupaya mencari meningkatkan produksi kopi dengan cara membentuk lembaga koperasi. Koperasi dapat membantu dan mempermudah petani dalam melakukan budidaya tanaman kopi, menyediakan sarana dan prasarana produksi, menyediakan pupuk, bibit serta menampung hasil panen. Koperasi Indonesia membangun dan mengembangkan potensi serta kemampuan ekonomi anggota pada khususnya dan masyarakat pada umumnya untuk meningkatkan kesejahteraan ekonomi, sosial potensi dan kemampuan ekonomi para anggota koperasi pada umumnya yang relatif kecil. Melalui koperasi, potensi dan kemampuan ekonomi yang kecil itu dihimpun sebagai satu kesatuan, sehingga dapat membentuk kekuatan yang lebih besar (Saptana et all, 2006). Tujuan penelitian ini 
adalah Menganalisis peran koperasi terhadap produksi kopi dan kesejahteraan petani. pendapat serta persepsi seseorang atau kelompok tentang kejadian atau gejala sosial(Situmorang et all, 2014). Dengan menggunakan skala likert maka dimensi dijabarkan menjadi variabel kemudian variabel tersebut dijabarkan menjadi indikator yang dapat diukur. Akhirnya indikatorindikator terukur ini dapat dijadikan titik tolak untuk membuat instrument berupa pertanyaan atau penyataan yang dijawab oleh responden. Skala yang digunakan untuk mengukur peran koperasi dalam meningkatkan produksi kopi dengan 4 pilihan skala likert dengan format skor dan kategorinya:

Skor 1. Sangat Tidak Setuju

Skor 2. Kurang Setuju

Skor 3. Setuju

Skor 4. Sangat Setuju

Untuk total skor dari setiap pertanyaan yang diajukan menggunakan Rumus berikut:

Total Skor $=\mathrm{T} \times \mathrm{Pn}$

Dimana:

$\mathrm{T}=$ Jumlah responden yang memilih $\mathrm{x}$ jumlah pertanyaan

Pn $=$ Pilihan angka skor likert 
Selanjutnya untuk medapatkan hasil interpretasi harus diketahui skor tertinggi (Y) dan angka terendah (X) untuk item penilaian dengan rumus berikut:

I = 100 / Jumlah Skor (likert)

Maka:

$\mathrm{I}=100 / 4=25$

$$
\begin{aligned}
& 0 \%-24,99 \%=\text { SangatKecil } \\
& 25 \%-49,99 \%=\text { Kurang } \\
& 50 \%-74,99 \%=\text { Besar } \\
& 75 \%-100 \%=\text { SangatBesar }
\end{aligned}
$$

$\mathrm{Y}=$ Skor Tertinggi Likert $\mathrm{x}$ jumlah responden $\mathrm{x}$ jumlah pertanyaan

$\mathrm{X}=$ Skor terendah Likert $\mathrm{x}$ jumlah responden $\mathrm{x}$ jumlah pertanyaan

Maka penilaian interpretasi responden terhadap besarnya peran koperasi terhadap produksi kopi dan kesejahteraan petani kopi di kecamatan bandar adalah nilai Index $\%$ dengan rumusnya berikut (Natsir, 2013).

NILAI INDEX \% = Total Skor $/$ Yx 100

Untuk mengetahui letak nilai index, terlebih dahulu Mengetahui interval (jarak) dan interprestasi persen dengan metode mencari Interval Skor Persen (I) sebagai berikut (Natsir, 2013): interprestasi skornya berdasarkan interval berikut:

Dengan ketentuan :

- Jika nilai index berada dalam interval $0 \%-24,99 \%$ maka peranan koperasi terhadap produksi kopi dan kesejahteraan petani kopi sangat kecil.

- Jika nilai index berada dalam interval $25 \%$ - 49,99\% maka peranan koperasi terhadap produksi kopi dan kesejahteraan petani kopi kecil.

- Jika nilai index berada dalam interval $50 \%$ - 74,99 \% maka peranan koperasi terhadap produksi kopi dan kesejahteraan petani kopi besar.

- Jika nilai index berada dalam interval $75 \%-100 \%$ maka peranan koperasi terhadap produksi kopi dan kesejahteraan petani kopi sangat besar. 


\section{HASIL DAN PEMBAHASAN}

\section{Peran Koperasi Terhadap Produksi Dan Kesejahteraan Petani Kopi}

Tabel 6. Peran Koperasi

\begin{tabular}{llll}
\hline No & Peran koperasi & Indeks & Kategori \\
\hline 1 & Penyediaan Bibit Kopi & 73,48 & Besar \\
2 & Penyuluhan & 78,33 & Sangat Besar \\
3 & Penyediaan Pupuk Organik & 79,84 & Sangat Besar \\
4 & Penampungan Hasil & 66,96 & Besar \\
5 & Premi & 76,21 & Sangat Besar \\
6 & Jumlah produksi & 81,81 & Sangat Besar \\
7 & Perkembangan Struktur Pendapatan & 78,18 & Sangat Besar \\
\hline
\end{tabular}

Tabel 6. Menjelaskan tentang

nilai indeks peran koperasi terhadap produksi dan kesejahteraan petani kopi dalam penyediaan bibit kopi, penyuluhan, penyediaan pupuk organik, penampungan hasil, premi, jumlah produksi, dan tingkatkesejahteraan.

\section{Penyediaan Bibit Kopi}

Penyediaan bibit kopi adalah bibit kopi yang disediakan oleh koperasi di Kecamatan Bandar untuk petani kopi merupakan bibit kopi varietas gayo 1,namun bukan hanya bibit kopi varietas gayo 1 saja yang disediakan oleh koperasi, masih ada beberapa bibit kopi yang disediakan oleh koperasi seperti bibit kopi varietas gayo 2 dan varietas P-88.

Penyediaan bibit kopi yang dilakukan koperasi kopi di Kecamatan Bandar dalam peneitian ini, nilai indeksnya73,48 \% (lampiran 3),nilai ini berada pada kategori besar. Mesikpun dengan nilai indeks begitu besar, petani belum begitu merata dan maksimal merasakan penyediaan bibit kopi dikarenakan penyediaan bibit kopi oleh koperasi dilakukan secara bertahap-tahap.

\section{Penyuluhan}

Penyuluhan merupakan suatu kegiatan yang dibentuk oleh koperasi kopi untuk kepentingan petani kopi dalam melakukan usahatani kopinya. 
Kegiatan penyuluhan yang dilakukan oleh koperasi untuk petani sangat berdampak positif dan diterima oleh petani kopi,terbentuknya penyuluhan kopi yang dilakukan koperasi dapat meningkatkan produksi kopi dan memotivasi petani agar lebih baik dalam membudidayakan kopi organik.

Dengan adanya arahan yang diberi oleh penyuluh, petani lebih mengerti bagaimana cara mengatasi masalah usahatani kopinya, seperti cara penanaman bibit yang lebih baik, cara pemupukan yang baik, cara pemangkasan, cara penanaman pohon pelindung dan cara penyetekan tanaman kopi. Hasil penelitian menunjukkan, penyuluhan yang dilakukan koperasi kopi terhadap petani kopi diterima dengan baik oleh petani kopi, nilai indeks peyuluhan kopi di Kecamatan Bandar sebesar $78,33 \%$ (lampiran 4), nilai ini berada pada kategori sangat besar.

\section{Penyedian Pupuk Organik}

Pupuk organik yang disediakan koperasi merupakan pupuk organik yang diolah. Dengan pupuk organik yang disediakan koperasi sangat membantu petani dalam meningkatkan usahatani kopinya.Pupuk organik yang digunakan petani kopi adalahpupuk yang bersertifikat IOM.

Selain pupuk organik yang diberikan oleh koperasi, petani juga menggunakan pupuk yang ada dikebun, seperti pupuk organik yang diolah dari kulit kopi yang difermentasikan. Penyediaan pupuk organik yang disedia oleh koperasi kepada petani mencukupi, namun koperasi memacu petani agar dapat menggunakan pupuk organik yang ada dikebun sendiri. Hasil penelitian menunjukkan, penyediaan pupuk organik yang diberikan koperasi kopi kepada petani kopi di Kecamatan Bandar sangat bermanfaat untuk petani kopi dalam melakukan usahataninya, nilai indeks penyediaan pupuk organik di Kecamatan Bandar sebesar 79,8 \% (lampiran 5), nilai ini berada pada kategori sangat besar.

\section{Penampungan Hasil}

Penampungan hasil adalah koperasimenampung seluruh hasil produksi kopi dari keseluruhan petani 
yang tergabung dalam koperasi. Penampungan yang disediakan koperasi untuk hasil panen kopi petani sangatlah berdampak positif untuk petani yang tidak mempunyai ruang yang begitu luas untuk penyimpanan kopinya.

Sebelum disimpan ke koperasi petani terlebih dahulu menyimpan hasil panennya dirumah sendiri.Setelah hasil panen kopi lebihdari $100 \mathrm{~kg}$ petani langsung membawa ke koperasi atau kolektor dari koperasi yang langsung mengambil dari petani.

Kopi yang telah dibawa petani kekoperasi atau diambil langsung oleh kolektor koperasi harus di dijemur lagi dikarenakan belum keringnya kadar air dari biji kopi tersebut, jika penjemuran kopi telah cukup baikmaka kopi siap untuk diekspor. Penampungan atau tempat penyimpanan hasil yang disediakan koperasi kopi di Kecamatan Bandar mempermudah petani dalam meyimpan dan menampung langsung hasil panen kopi dikoperasi. Hasil penelitian ini menunjukkan, nilai indeks penampungan hasil di
Kecamatan Bandar sebesar 66,9\% (lampiran 6), nilai ini berada pada kategori besar.

\section{Premi}

Premi adalahsuatu keuntungan yang didapat dari akhir penjualan hasil kopi petani yang dinyatakan dalam bentuk persen, premi bisa di dapat dari hasil akhir penjualan kopi yang dijual oleh koperasi disetiap tahun. Adanya premi membantu petani lebih mudah dalam mengelola usahataninya.

$$
\text { Hasil penelitian ini }
$$
menunjukkan bahwa, nilai indeks premi di Kecamatan Bandar sebesar 76,2\% (lampiran 7), nilai ini termasuk pada kategori sangat besar.Pengembalian premi yang dilakukan koperasi sangatlah berguna dan bermanfaat bagi petani kopi untuk melakukanusahataninya, sehingga petani dapat meningkatkan hasil produksi dan kualitas yang baik.

\section{Jumlah Produksi}

Jumlah produksi adalah hasil akhir dari proses produksi kopi yang didapatkan oleh petani, jumlah produksi yang dihasilkan oleh petani 
tidak lepas dari peran koperasi dengan cara membagikan pupuk organik, penyediaan bibit kopi, dan melakukan penyuluhan.

Penyuluhan tersebut memberi motivasidan mengarahkan petani untuk membudidayakan kopinya dengan lebih baik.Dengan adanya kerja sama antara koperasi kopidengan petani kopikemungkinan hasil produksi kopi lebih tinggi dan kualitas kopi lebih baik. Hasil penelitian ini menunjukan bahwa jumlah produksi kopi di Kecamatan Bandar mempunyai nilai indeks sebesar 81,8\% (lampiran 8), nilai ini termasuk dalam kategori sangat besar.

Koperasi sangat berperan dalam peningkatan jumlah produksi kopi.

\section{Kesejahteraan}

Kesejahteraan $\begin{array}{r}\text { petani } \\ \text { kopidiukur dengan }\end{array}$ struktur
pendapatan yaitusumber pendapatan
utama keluarga petani dari sektor
mana saja dalam memenuhi
kebutuhan hidupdan tanggungan bagi
keluarganya.Struktur
pendapatanrumah tangga petani
dijadikan sebagai indikator untuk

mengukur tingkat kesejahteraan petani.

Hasil penelitian menunjukkan bahwa struktur pendapatan rumah tangga petani kopiyang tergabung dalam koperasi di Kecamatan Bandar yaitu lebih besar dari usahatani kopi. Indikator kesejahteraan mempunyai nilai indeks yang termasuk dalam kategori sangat besar yaitu mencapai $78,1 \%$. Koperasi memiliki peran yang sangat besar dalam meningkatkan kesejahteraan petani.

\section{KESIMPULAN}

1. Peran koperasi kopi terhadap produksi dan kesejahteraan petani di Kecamatan Bandar yaitu sangat besar.

2. Peran koperasi kopi dalam melakukan penyuluhan, penyediaaan pupuk organik dan premi termasuk dalam kategori sangat besar, sedangkan peran koperasi terhadap penyediaan bibit kopi dan penampungan berada pada kategori besar, koperasi juga sangat berperan dalam peningkatan kesejahteraan petani kopi. 


\section{DAFTAR PUSTAKA}

Abdurachman, A., Dariah, A., \& Mulyani, A. (2008). Strategi dan teknologi pengelolaan lahan kering mendukung pengadaan pangan nasional. Jurnal Litbang Pertanian, 27(2), 43-49.

Dinas Perkebunan dan Kehutanan Kabupaten Bener Meriah. (2013). Hasil Produksi dan Luas Lahan Kopi Di Kabupaten Bener Meriah dari Tahun 2008 - 2012.

Hasan, I. (2011). Penguatan Kompetensi Kewirausahaan dan Daya Saing UKM Komoditi Unggulan Ekspor di
Propinsi Aceh. Jurnal Infokop, 19, 38-52.

Saptana, S., Sunarsih, S., \& Indraningsih, K. S. (2006). Mewujudkan keunggulan komparatif menjadi keunggulan kompetitif melalui pengembangan kemitraan usaha hortikultura. In Forum Penelitian Agro Ekonomi (Vol. 24, pp. 61-76). Indonesian Center for Agricultural Socioeconomic and Policy Studies.

Situmorang, S. H., Muda, I., Doli, M., \& Fadli, F. S. (2014). Analisis data untuk riset manajemen dan bisnis. USUpress. 